\title{
Space imagination and mixed identity in Russian towns bordering on Finland
}

\author{
Igor Okunev, Aleksey Domanov*
}

MGIMO-University, Russia

The quantitative analysis of an opinion poll conducted in October 2013 in three Russian cities located near Finnish border (St-Petersburg, Kronstadt and Vyborg) explores European identity of their citizens. This area was chosen to illustrate the crucial importance of space interpretation in spatial identity formation by using critical geopolitical approach. The study shows how different images of space on the same territory act as intermediate variables between objective territorial characteristics and citizens' identities. As the geographical position at the border of Russia provides the citizens with geopolitical alternatives to identify their location as a fortress defending the nation (as in the case of Kronstadt) or a bridge between cultures, the given study allows us to compare reasons for these geopolitical choices of inhabitants. Furthermore, the research aims at bridging the gap in the studies of European and multiple identity in Russian regions and provides Northwest Russian perspective on the perpetual discussion about subjective Eastern border of Europe.

Key Words: Russia-Finland border, European identity, Space imagination, Critical geopolitics.

Article Info: Received: July 27, 2014; Revised: October 28, 2014; Accepted: November 14, 2014; Online: November 30, 2014.

\section{Introduction}

In October 2013 the Club for Geopolitical Studies of MGIMO-University organized a research expedition to three cities in the border area of Russia and Europe: St. Petersburg, Vyborg and Kronstadt. The expedition was an attempt to answer the following research question: how did bordering position affect the identity of inhabitants of these cities and towns. At the same time, we proceeded from the axiom that identity can affect political processes in these cities to some

\section{* Corresponding author}

Address: School of Political Affairs, MGIMO-University, 76, Prospect Vernadskogo, Moscow, 119454, Russia.

Email: domanov.aleksey@gmail.com 
extent. In particular, we assume that various identity (for example, European, Russian, Finnish) determines difference in voters' political culture and ideological preferences, which cannot help but affecting political process.

Nevertheless, we put aside the way in which various identities shape various political practices. We aimed at showing how space shaped these identities. Following the traditional logic of geopolitics, particular space would necessarily shape a particular type of spatial identity, which would vary in intensity depending on the intensity of the spatial characteristic. For instance, the area at the Russian-Finnish border should have given rise to a more European (or mixed) type of spatial identity. In this case spatial identities in Vyborg, Kronstadt and St. Petersburg would be affected by the border characteristic to different degrees.

The thesis was to be checked during our expedition. Relying on critical geopolitics, we initially hypothesized that space by itself does not shape a specific identity. There is a mediator in the causal link between space and identity interpretation of space. Any space can be interpreted differently, and even in opposite ways. If the assumption is correct, uniform space (in this case, border area) must have been interpreted differently, which in turn must have engendered different identities.

The hypothesis was checked in cities situated in the same border area (not far from Russian-Finnish border) - St. Petersburg, Vyborg and Kronstadt. ${ }^{1}$ The research group employed a range of qualitative and quantitative methods from discourse analysis to standardized public opinion poll, but only the latter will be analyzed below.

The opinion poll was conducted in order to answer the following research questions: can St. Petersburg be considered "our foreign area"? Do Vyborg citizens feel living on "occupied territory"? Are Kronstadt citizens attached more to their locality than to Russia and Europe (what is more important for them)?

Our field study revealed two types of spatial features that are subject to citizens' interpretation. The first type includes the features that were interpreted differently in every town:

1) border location/ marginality can be interpreted bearing in mind either the barrier function of a border, which results in the protective and traditional identity of a town-fortress defending a country's border (Kronstadt), or its contact function, which leads to the mixed, polycultural identity of a townbridge connecting territories on both sides of the border (Vyborg, St.Petersburg);

2) peripheral location can be interpreted either as backwardness in comparison to the center, which reinforces national identity (Kronstadt, St.Petersburg), or as an opportunity to shape own local historical narratives, which supplement national identity (Vyborg).

The second type includes the features that played their role in shaping identity or not:

1) seaside location (interpreted in St.Petersburg and Kronstadt, but not in Vyborg);

2) proximity to Europe (interpreted in St.Petersburg and Vyborg, but not in

${ }^{1}$ More on the social dynamics of this region: in the past (Kalinitchev 2011) and nowadays (Petrov 2008, Semyonov and Abramov 2011). 
Kronstadt);

3) isolation (interpreted as exceptionality requiring that the nation state paid special attention to the area - only in Kronstadt).

Thus, we can talk about a special link in the chain of spatial identity formation - interpretation of space (expressed in spatial myths, images and conceptions). This link appears to be crucial, as it makes possible to shape different identities, including opposite ones. In turn, this fact proves that geographical variables do not determine, but only condition political processes. In other words, the variables set corridors and probable scenarios for them.

In this respect the given territories are of great interest, because they have Swedish heritage, but are now parts of Russian state. People of different nations could leave different imprints and could interpret the same space in different ways. St.Petersburg and Kronstadt areas became Russian territories in the early 18 century, while Vyborg passed to Russian jurisdiction only in 1940, having stayed in Finland. Moreover, during Soviet times Vyborg was populated by migrants from other areas of the USSR, whose background had little similarity with Finnish self-consciousness of indigenous people. After all, some inhabitants of Kronstadt could have traits of "torn identity", as the town was built by Peter the Great on an island, so the people have limited access to the other parts of their nation state.

\section{Factors of Mixed Identity Construction}

The theoretical base of the study is the constructivist trend developing in the political science as a whole and geopolitics, in particular. It combines elements of the modernistic (positivist-rationalist) epistemology and postmodern (reflectivist) picture of the world. Such a combination corresponds to the process of research paradigm change that started after the emergence of postmodern criticism and came over social sciences and humanities and has now reached geopolitics. The combination allows using separate findings of classical geopolitics of the modern, yet, it limits reference to geographical determinism, ecocentrism and social Darwinism, as well as largely widens the understanding of space aspects of politics thanks to including in the problem field the research issues of the postmodern critical geopolitics.

The space (geopolitical) factors are interpreted in a wide sense here and compared with time (chronopolitical) ones. This helps achieve the objective of studying the maximum possible number of factors of impact on the political development. The focus is made not on the analysis of only the properties of the space object location, which are immanently inherent to it ("vertical conditionality"), but on the analysis of its relationship to the locations of other objects in space, i.e., on the analysis of space links ("horizontal conditionality"). The paper thus analyzes the impact of geopolitical (static) characteristics on chronopolitical (dynamic) characteristics.

The paper is based on the two principal theoretical and methodological approaches. The first one is related to the concept of multidimensionality and multiformity of political institutions and processes with mutual conditionality of space, and not only space, factors of state development. The second approach is 
associated with the recognition of cognitive limitations of various ideal constructs (abstract ideas, categories, ideal types, etc.), the incompleteness of their explanatory power and, hence, the necessity of empirical assessment of the extent of actual validity of certain state development factors in specific conditions.

One of these factors of state development is local self-consciousness. If the given opinion poll shows a serious cleavage and no link between groups of citizens putting a premium on their Russian, local and European identities, one can forecast that the cleavage would in future hinder the growth of state institutions on this territory. Strong local identity eclipsing national one would mean the beginning of Russian polity fragmentation in accordance with the Balkanization pattern of state-building process (Troncota 2011: 90). At the worst, strong desire to secede could appear among those with local or European identity. On the contrary, the presence of multilevel identity could reinforce territorial cohesion and minimize risks of political instability related to the claims of secession. Moreover, multilevel identity facilitates the establishment of transnational ties possible and, consequently, weakens the basis for radical nationalism.

A small review of literature will help to establish the most probable directions of causal links between spatial identity and its factors. Following constructivist logic of identity formation, it is shaped during discussion, exchange and transborder contacts (Checkel and Katzenstein 2009). For instance, it is cognitive mobilization of citizens that contributes to identity formation process (Inglehart 1970). In other words, citizens need information (Fuchs 2003) about members of their in-group or about the territory (e.g., of their nation state). Therefore, such variables like education level could influence identity feeling. Developing the above-mentioned idea of Checkel and Katzenstein, the survey measured effects of discussions about events in other European countries (as people also get information about in-group from other people), visiting other European countries (transborder contacts) and communicating with friends or relatives abroad.

Besides, Schild (2001) focused on affective dimension of spatial identity, so cultural relations with other Europeans could be as well a significant predictor. This parameter was measured with a question about listening to European music. Another cultural parameter, historical memory, also seems to affect spatial identity by giving a sense of common past with other Europeans, which fosters present unity.

Studies of spatial identity gave particular attention to its political (Duchesne and Frognier 2002) or civic (Bruter 2005) dimension. Consequently, such political factors as trust in authorities was also expected to affect spatial identity. Moreover, Schild highlighted its evaluative component (i.e. assessments of authorities can affect identity - Schild 2001).

Thus, these characteristics are believed to cause identity and not just be connected with it:

H1: European identity in this area is caused by trust in national authorities, consumer preferences (of European food, goods, music and trips to other European countries) and the degree of cognitive mobilization (education level, historical memory and frequency of discussion of events in other European countries). 


\section{Methodology}

The hypothesis was checked by analysis of variance (ANOVA) and correlation analysis of 185 answers of St.Petersburg, Kronstadt and Vyborg inhabitants.

Measurement of the dependent variable (European identity of Russian citizens) required taking into account other identity levels, so the poll measured if the respondents mentioned European identity among other types ("Do you consider yourself European?") or placed it above the other identities ("Who do you think you are in the first place?"). The point is that even EU citizens cannot identify themselves with the EU without attachment to their locality and nation (Haas 1958), with some scholars affirming that national identity in EU member states is inseparable from European and itself contains "aspects of Europeanness" ("marble cake" concept - Risse 2005). So we could expect the same phenomenon on Russian territory, where European identity was not so widespread. Here European identity could also be "anchored" in national one (Díez Medrano 2003; Duchesne 2008).

The respondents have also answered the following questions:

- how often do you discuss events in other European countries with other people?;

- do you prefer going to foreign European countries or to other places in Russia? - both for business and tourist purposes;

- do you prefer buying European or Russian food?;

- do you prefer buying European or Russian goods?;

- do you prefer listening to European or Russian music?;

- do you trust Russian national authorities? ;

- do you have friends or relatives born or living in foreign European countries?.

Our interest in the accuracy of historical memory was reflected by the following question: "When did this locality become a part of Russia?" Citizens of Vyborg were asked to name the former Finnish name of the city and if they believed their town was Russian, Finnish or Swedish (as expected, the respondents understood that the last question was about Finnish and Swedish cultural heritage, not administrative position). Demographic variables included age (sixpoint scale), level of education and occupation.

\section{European Identity in Relation to Others in North West Russia}

In all the three cities there were $4.4 \%$ of respondents placing their European identity above Russian and local one. The finding is rather close to results of other polls (for example, according to the European values study, $4.9 \%$ of inhabitants in North-Western federal district had European identity in 2008 Domanov and Zhirnova 2014), and this fact increases our confidence in the reliability of other findings. (Figure 1). $46.2 \%$ put Russian identity on the first place and $49.5 \%$ - local one. At the same time, the majority (64.5\%) mentioned European identity, but did not specify what place it had on their list.

Respondents varied significantly (with the acceptable significance of Chisquare coefficient .005) in their musical preferences: European music was listened to by $47.3 \%$ of those polled in St. Petersburg, by $36.7 \%$ - in Kronstadt 


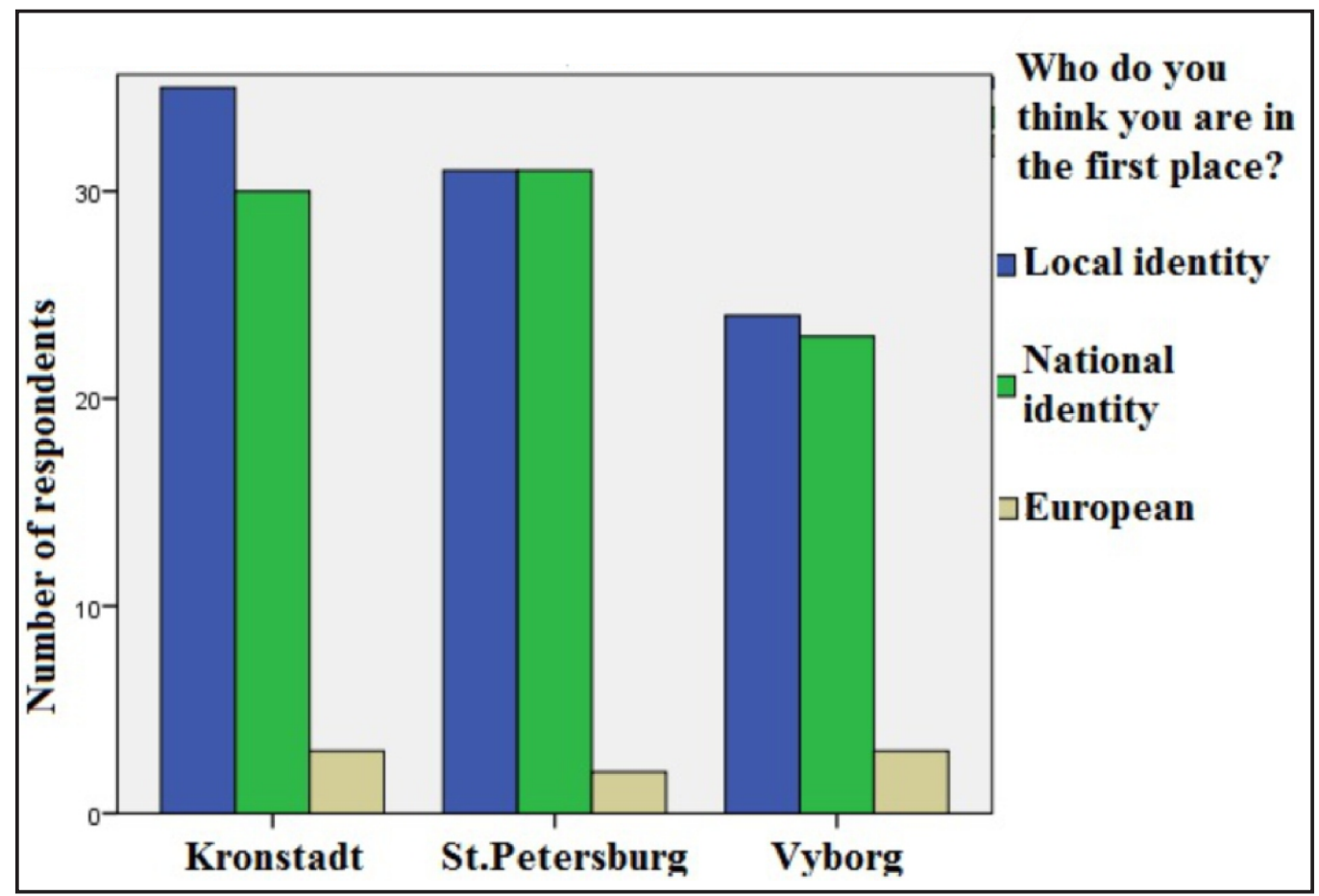

Figure 1. "First-order" identity in these towns.

and only by $17 \%$ in Vyborg. The number of respondents preferring trips to foreign European countries also varied significantly: 31.3\% in Kronstadt, 50\% in Vyborg and $61.3 \%$ in St. Petersburg.

The last finding is believed to reflect the objective geographical isolation of island-based Kronstadt and its relatively poor living standard. However, Kronstadt citizens can also have a psychology of "besieged fortress", as the question concerned preferences rather than real capabilities of the respondents. In other words, if the respondents understood the question correctly, the finding means that people did not feel any desire to go abroad even if they had resources to do so. The qualitative analysis carried out by other members of our research group confirmed that Kronstadt was still considered "Russian stronghold", with inhabitants believing it was their duty to protect Russia from Western threat (like under Peter the Great or during WWII).

\section{Causes of European Identity in North West Russia}

As hypothesized, trust in national authorities and two groups of factors were found to engender European identity and its priority over other spatial identities. Insignificant results can mean that there is a relationship, but further studies on larger sample are needed: poor significance is often caused by small number of respondents.

\section{A. Trust in national authorities}


The character of this link appeared to be the most surprising. European aspirations were expected to be widespread among people unwilling to be governed by the current Russian authorities, like among Russian emigrants of the 20th century.

However, European identity was mentioned more often by the respondents who trusted national authorities (by $75.8 \%$ of those who trusted vs. $58 \%$ of those who did not trust, Chi-square significance under 10-percent level: .075). These characteristics were even found to be correlated (Spearman coefficient -.167 with significance $p=.076$ ). The same kind of relationship was observed in the case of "first order" European identity, but poor significance of the result means a necessity to conduct further surveys with larger sample to get a more solid proof.

The finding can be explained by a latent factor - general satisfaction with life of those who trust national government. It is possible that satisfied people are both grateful to the authorities for good socioeconomic conditions and maintain the high living standard, which they associate with European prosperity (e.g. they can afford to buy goods of high quality).

\section{B. Consumer preferences (food, goods, music, trips)}

Preference of food produced in other European countries appeared to be related to European identity. Indeed, $87.5 \%$ of consumers of European food considered themselves Europeans, while only $61.3 \%$ of consumers of Russian food had this identity. The significance of Chi-square is .017 .

Moreover, it is very probable that this preference is related to the "first-order" European identity. Respondents preferring to buy European food were more inclined to place European identity above all than those liking Russian food: $1.9 \%$ vs. $10.2 \%$ of these respective groups with even more significant Chi-square (less than .001). Besides, "first-order" European identity also seems to be caused by preferences of European goods (5.9\% of such respondents vs. 1.9\% among fans of Russian goods) and music (9.1\% of Europeans among the fans of European music and 2.9\% - of Russian music). The significance of Chi-square coefficients in both cases is also acceptable: .077.

Furthermore, an interesting observation can shed light on the psychology of "besieged fortress": maybe, the more practices connect people to foreign countries - the more they feel isolated from the rest of Russia, and as a result they often overshadow national identity by another type (European or local one). In all the three cities (not only in Kronstadt, where the "besieged fortress" psychology was expected) the people who liked foreign food, goods and music placed European and local identity above national one more often than those who liked Russian food (63.3\% vs. $39.8 \%)$, goods (54.8\% vs. $40.4 \%)$ and music $(52.7 \%$ vs. $43.8 \%$ ).

Desire to visit foreign European countries seems to make people place European identity above other identities. There are twice more "first-order" Europeans among people with this preference (6.1\%) than among people willing to go to Russian places (3.2\%). However, as many respondents could not give definite answer to that question, the number of observations narrowed and 
Table 1. Respondents with European and local identity on the first place.

\begin{tabular}{|c|c|c|c|c|c|c|}
\hline \multirow{2}{*}{} & \multicolumn{2}{|c|}{ Food } & \multicolumn{2}{c|}{ Goods } & \multicolumn{2}{c|}{ Music } \\
\cline { 2 - 7 } & Russian & European & Russian & European & Russian & European \\
\hline European identity & $1.9 \%$ & $10.2 \%$ & $1.9 \%$ & $5.8 \%$ & $2.9 \%$ & $9.1 \%$ \\
\hline Local identity & $39.8 \%$ & $63.3 \%$ & $40.4 \%$ & $54.8 \%$ & $43.8 \%$ & $52.7 \%$ \\
\hline
\end{tabular}

caused poor significance of Chi-square coefficient.

\section{Cognitive mobilization (level of education, frequency of discussion and historic memory)}

The level of education appeared to be related to "first order" European identity: the number of people placing European identity above others varied from $51.4 \%$ among people with full secondary education to $72.4 \%$ among people with higher education. There was even a linear correlation between mentions of European identity and education level (Spearman coefficient .175 with significance $\mathrm{p}=.056$ ).

Furthermore, the more people discussed events in foreign European countries - the more likely they were to identify themselves as Europeans. European identity was mentioned by $56.5 \%$ of the people who spare no time for discussing these events, by $64.9 \%$ of the people who sometimes discussed these events and by $70 \%$ of those who often discussed these events.

In turn, this frequency of discussion was partially determined by the presence of friends or relatives in foreign European countries (linear correlation coefficient .112 with significance .129 , which could be better in larger sample) and by education level (coefficient .156 with significance .034).

In addition, if people were aware of their localities' admission to Russia, they were more likely to call themselves Europeans than people with inaccurate historic memory (for example, who thought that Vyborg area entered into Russia in the beginning of 19th century): Spearman correlation coefficient .172 with significance .086. Moreover, people with good historical memory were more likely to place European identity above other types (coefficient .139 with significance .049). Similarly, the better people knew former names of their cities, the more likely they were to identify themselves as Europeans. For instance, the old Finnish name of Vyborg (Viipuri) was remembered by $64.1 \%$ of "Europeans" and by $35.9 \%$ of "non-Europeans".

However, in spite of such good memory of Finnish roots, there is not enough evidence to substantiate that Vyborg citizens feel living on "occupied territory". Although 27.3\% of Vyborg citizens considered their town a Finnish one and $29.5 \%$ - a Swedish one, they orally clarified that they meant it in cultural sense, recognized that the town administratively belonged to Russia and did not want to leave Russian jurisdiction. This fact can be attributed to their Russian or local "first-order" identities: they did not want to leave Russia because they lived in 
the same country as their imagined community. Indeed, only $12 \%$ of the people considering Vyborg a Finnish or a Swedish town were primarily Europeans.

In-depth interviews taken for qualitative analysis by members of our research group showed (Okunev and Savin 2014) that many Vyborg inhabitants immigrated from other Russian territories after 1940, so they do not cling to life under Finnish government and do not consider the USSR or Russia "occupation regimes".

\section{Conclusion}

The most important theoretical result is that interpretation of space plays key role in spatial identity formation, acting as an intermediate variable between objective territorial characteristics and citizens' identities. Different images of space on the same territory shape different identities, as shown on the example of European, Russian and local identity in three near towns.

Empirically, European identity in Russian regions was proven to be caused by trust (surprisingly, not distrust) in national authorities, consumer preferences (of European food, goods, music and trips to other European countries) and the degree of cognitive mobilization (education level, historical memory and frequency of discussion of events in other European countries). The link between trust in authorities and European identity can be attributed to general satisfaction with life of some respondents (they can associate their high living standard with European lifestyle and explain it with efficient national government). Nevertheless, additional inverse causal links cannot be excluded.

Besides, there are differences across cities by musical preferences and desire to go to other European countries. The citizens of Kronstadt were the most unwilling to go there, which may be a proof of subjective isolation of this town.

As to Vyborg citizens' space perception, there is little evidence that they feel being on occupied territory (probably due to Russian origin of many inhabitants). Comparing the tightness of established linear dependences, one can notice almost equally tight links between European identity and education level (Spearman coefficient .175), between European identity and historical memory (.172), and between European identity and trust in national authorities (-.167). Nevertheless, if a policymaker aims at affecting European identity feelings of the largest number of citizens, he or she would most likely succeed by changing education level. At the same time, further studies are needed to completely assess the efficiency of this influence on every citizen (regression analysis that would require larger sample).

\section{Acknowledgements}

The authors would like to thank MGIMO-University and MGIMO Development Foundation for financing this project and other members of the research group from Club for Geopolitical Studies for their help in field work and additional qualitative analysis of the data (Valeria Bakhchivanzhi, Darya Basova, Nadezhda Manzhina, Sergey Savin, Polad Talybov and Lidia Zhirnova). 


\section{References}

Adaskina, V, Vassel, I, Zuev, B \& Rior, E 1965, Znakomtes' - Vyborg, Lenizdat Leningrad, viewed 12 November 2012, http://www.188800.ru/1965/012.htm.

Bolshakova, G 2009, Vyborg Sovetskiy: Iz Istorii Stanovleniya i Razvitiya Goroda v 1940-e gody, Vestnik Udmurtskogo Universiteta. Istoriya $i$ Filologia, no. 2, pp. 71-86, viewed 10 October 2012, http://vestnik.udsu.ru/2009/2009-052/vuu_09_052_05.pdf.

Bruter, M 2005, Citizens of Europe? The Emergence of a Mass European Identity, Palgrave Macmillan, New York.

Checkel, J \& Katzenstein, P 2009, European Identity, Cambridge University Press, Cambridge.

Díez Medrano, J 2003, Framing Europe: Attitudes to European Integration in Germany, Spain, and the United Kingdom, Princeton University Press, Princeton,

Domanov, A \& Zhirnova, L 2014, Evropejskaya identichnost' v rossijskih regionah kak komponent mnozhestvennoj prostranstvennoj identichnosti, in M Gorny, \& A Sungurov (eds.) Publichnaya politika, pp. 171-175, Norma, Saint-Petersburg.

Duchesne, S \& Frognier, AP 2002, Sur les dynamiques sociologiques et politiques de l'identification à l'Europe, Revue française de science politique, vol. 52, no. 4, pp. 355-373.

Duchesne, S 2008, Waiting for a European Identity ... Reflections on the Process of Identification with Europe, Perspectives on European Politics and Society, no. 4, pp. 397-410.

Fuchs, C 2003, Globalization and Self-Organization in the Knowledge-Based Society, TripleC, no. 2, pp. 105-169.

Haas, E 1958, The Uniting of Europe, Stanford University Press, Stanford.

Inglehart, R 1970, Public Opinion and Regional Integration, International Organization, no. 4, pp. 764-795.

Kalinitchev, A 2011, Ethnic Migration in North-West Ingermanland: The Influence of Economic Development on Local Differences in the Second Half of the 19th Century, Finnish Yearbook of Population Research, vol. XLVI, pp. 95-114, viewed 22 October 2012, http://www.vaestoliitto.fi/@Bin/1391545/YB\%202011_pp.95-114.pdf.

Okunev, I \& Savin, S 2014, Kriticheskaya geopolitika, vol. 1, Analitika Rodis, Noginsk.

Petrov, A 2008, Lost Generations? Indigenous Population of the Russian North in the Post-Soviet Era, Canadian Studies in Population, vol. 35, no. 2, pp. 269-290, viewed 20 October

2012 http://www.canpopsoc.ca/CanPopSoc/assets/File/publications/journal/CSPv35n2p269.pdf.

Risse, T 2005, Neofunctionalism, European Identity, and the Puzzles of European Integration, Journal of European Public Policy, no. 2, pp. 5.

Schild, J 2001, National versus European Identities? French and German in the European Multi-Level System, Journal of Common Market Studies, no. 2, pp. 331-351.

Semyonov, S \& Abramov, P 2011, Migration processes in the formation of the population of the Russian Northwest, Regional Research of Russia, vol. 1, no. 3, pp. 240-243, viewed 15 October 2012, http://link.springer.com/article/10.1134\%2FS2079970511030129.

Troncota, M 2011, Balkanization of the Europeanization Process, Western Balkans Security Observer, vol. 6, no. 21, pp. 64-90. 